\title{
Application of PCR amplification of DNA from paraffin embedded tissue sections to linkage analysis in familial retinoblastoma
}

\author{
Z Onadim, J K Cowell
}

\begin{abstract}
A family segregating for the retinoblastoma predisposition gene has been analysed using the polymerase chain reaction to exclude their son as being an affected gene carrier. The unusual feature of this family is that the affected child, who would ordinarily have been used to establish phase in a linkage study, died as a result of developing a second tumour some years ago. The only tissue available from this child was a paraffin embedded, formalin fixed histopathological specimen from the second tumour. It was possible to isolate DNA from this tissue and amplify the DNA flanking two polymorphic restriction enzyme sites to establish alleles which cosegregated with tumour predisposition. Archival material can now be used to offer families such as this prenatal screening to provide informed genetic counselling.
\end{abstract}

Retinoblastoma $(\mathbf{R b})$ is the most common intraocular tumour of children. In its familial form the tumour phenotype segregates as an autosomal dominant trait. ${ }^{1} \mathrm{Rb}$ arises as a result of mutations in both copies of the $\mathrm{Rb}$ gene. ${ }^{2}$ Most cases are apparently sporadic, owing to random key mutations in both genes; in hereditary cases ( 25 to $40 \%$ ), however, the first mutation is transmitted through the germline and only the second mutation occurs as a random somatic event. Subjects carrying the $\mathbf{R b}$ predisposition gene are also at a significantly higher risk than the general population for development of a number of other tumours, especially osteosarcoma and soft tissue sarcomas. $^{3} 4$

Through the analysis of rare constitutional chromosomal deletions ${ }^{56}$ and classical linkage studies using

ICRF Laboratory of Molecular Genetics, Department of Haematology and Oncology, Institute of Child Health, 30 Guilford Street, London WCIN 1EH.

Z Onadim, J K Cowell

Correspondence to Dr Cowell.

Received for publication 25 September 1990.

Accepted for publication 9 November 1990 the adjacent esterase $\mathrm{D}$ gene, ${ }^{7-9}$ the $\mathrm{Rb}$ gene was mapped to chromosome region $13 \mathrm{q} 14$ and these observations eventually led to its isolation..$^{10-12}$ The gene, called $R B 1$, is $4.7 \mathrm{~kb}$ long and spans $200 \mathrm{~kb}$ of genomic DNA. ${ }^{12-14}$ The $4 \cdot 7 \mathrm{~kb}$ mRNA comprises 27 exons and structural rearrangements have been observed within the genomic sequence and mRNA of approximately $30 \%$ of tumours. The cDNA cannot be used directly in linkage studies, because it does not identify polymorphic sites for restriction enzymes. Therefore a series of unique sequence, intragenic DNA probes were isolated ${ }^{15}$ allowing gene tracking in families and the detection of apparently unaffected $R b$ gene carriers. ${ }^{16}$ The sequence for the entire Rb cDNA is now available ${ }^{13}{ }^{17}$ and the flanking intron sequences around two of the polymorphic sites have also been determined. ${ }^{18-20}$ This means that linkage analysis in $\mathrm{Rb}$ families can be performed using the polymerase chain reaction (PCR).

The intragenic DNA probes are used in our laboratory for pre- and postnatal screening for $\mathbf{R b}$. However, between $10 \%$ and $15 \%$ are either uninformative for these probes or DNA samples have not been available from key family members. Here we present one such family, whose first child would normally have been used to establish linkage phase but who died before DNA analysis was available.

\section{Materials and methods \\ DNA PREPARATION}

DNA from whole blood samples was prepared using standard phenol/chloroform extraction followed by ethanol precipitation. ${ }^{21}$ DNA from $10 \mu \mathrm{m}$ thick paraffin embedded tumour sections was prepared by a method modified from Shibata et al. ${ }^{22}$ Firstly, individual paraffin sections were dissolved in $500 \mu \mathrm{l}$ of xylene. The tissue was recovered by centrifugation and then washed twice in ethanol and desiccated for 0.5 to 2 hours. The DNA extraction solution consisted of $100 \mathrm{mmol} / \mathrm{l}$ Tris-Cl, $4 \mathrm{mmol} / 1$ EDTA pH $8 \cdot 0$, and $0.5 \mathrm{mg} / \mathrm{ml}$ proteinase $\mathrm{K}$. After 12 to 18 hours at $37^{\circ} \mathrm{C}$, this solution was boiled for seven minutes and 1 to 10 $\mu l$ used for PCR. 


\section{PCR BASED DETECTION OF POLYMORPHIC SITES}

\section{BamHI site}

Two primers (table), one from exon 1 and the other from intron 1 of the human $\mathrm{Rb}$ gene, were used to amplify a genomic DNA fragment containing the polymorphic BamHI site. In conventional Southern blotting experiments this polymorphism is identified using the M1.8 DNA probe. PCR was carried out in a total volume of $50 \mu \mathrm{l}$ containing approximately $1 \mu \mathrm{g}$ DNA and Promega buffer consisting of $50 \mathrm{pmol}$ of each primer, $0.2 \mathrm{mmol} / \mathrm{l}$ each dNTP (dATP, dTTP, dCTP, dGTP), $50 \mathrm{mmol} / \mathrm{l} \mathrm{KCl}, 10 \mathrm{mmol} / \mathrm{l}$ Tris $\mathrm{HCl}$ (pH 9.0 at $25^{\circ} \mathrm{C}$ ), $1.5 \mathrm{mmol} / 1 \mathrm{MgCl}_{2}, 0.01 \%$ gelatin (w/v), $0 \cdot 1 \%$ Triton $\mathrm{X}-100,10 \%$ dimethyl sulphoxide (DMSO), and 2 to 3 units Taq DNA polymerase (Promega). The reaction mix was overlaid with $50 \mu \mathrm{l}$ of mineral oil to prevent evaporation. Amplification was performed using a programmable thermal cycler (Techne PHC-1). Amplification conditions consisted of three steps (after an initial 15 minute denaturation step at $96^{\circ} \mathrm{C}$ ): denaturation at $96^{\circ} \mathrm{C}$ for 20 seconds, annealing at $60^{\circ} \mathrm{C}$ for 20 seconds, followed by an extension step at $72^{\circ} \mathrm{C}$ for 60 seconds. On completion of 30 cycles the mineral oil was removed by chloroform extraction. The amplified product was then digested overnight with BamHI. DNA fragments were resolved by electrophoresis through $2 \%$ agarose gels.

\section{XbaI site}

A genomic DNA fragment containing the polymorphic $X b a I$ site $(21.8 \mathrm{~kb}$ downstream of exon 17) was amplified using primers (table) from intron 17 of the human Rb gene. Using conventional Southern blotting procedures this polymorphism is identified by the PRO.6 DNA probe. The PCR conditions were the same as those used for the BamHI site except that the PCR mix did not contain DMSO and the annealing temperature was $50^{\circ} \mathrm{C}$. The amplification product was digested overnight with $X b a I$. DNA fragments were resolved by electrophoresis through $1 \cdot 4 \%$ agarose gels.

\section{Results and discussion}

Prenatal screening for carriers of the RB predisposition gene is now relatively routine using a panel of unique DNA sequences derived from within the genomic sequence of RB1. 152324 The polymorphic variants identified using these probes are sufficiently common in the population to offer a prediction of carrier status in 85 to $90 \%$ of families ${ }^{24}$ (unpublished observations). To date, there have been no reported recombinations between the intragenic probes and the $\mathrm{Rb}$ phenotype, allowing predictions to be made with $95 \%$ confidence. There are, however, still families for whom this service is not available. Approximately 8 to $10 \%$ of families will be uninformative using the available probes because family members transmitting the predisposition to tumour development are homozygous at all of these loci. The application of new technology looking at short variable number tandem repeats (VNTRs) around exon 20 of the Rb gene ${ }^{1825}$ or at single base pair polymorphic sites by direct sequencing ${ }^{26}$ offers the possibility of prenatal screening in these cases. There are some families, however, where prenatal screening is not an option because, for a variety of reasons, tissue samples from key family members are not available. One such family is the subject of this report.

The pedigree of family RB-29 is shown in fig 1 . At the age of 18 months the mother developed a tumour in the right eye which was enucleated. There was no previous history of $\mathbf{R b}$ in this family. There was no history of $\mathbf{R b}$ on the paternal side of the family either. At the age of 2 years the first born child, a girl, was treated for bilateral $\mathrm{Rb}$ with radiation. The tumour regressed but six months later a rhabdomyosarcoma arose in the right cheek and eventually caused the patient's death. ${ }^{27}$ Although a rare subtype of this tumour, this second malignancy was part of the group frequently seen in $\mathrm{Rb}$ gene carriers. ${ }^{34}$ The second child, a boy, was born in 1987 and the family was referred to us for genetic screening. The mother was shown to be heterozygous using the M1.8 and PRO.6 DNA probes described by Wiggs et al. ${ }^{15}$ The boy had

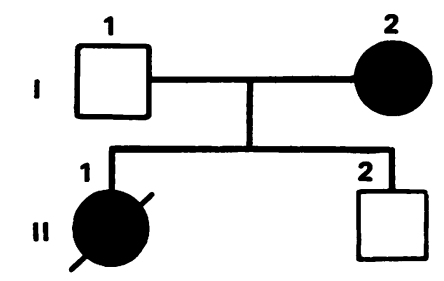

Figure 1 Pedigree of family RB-29.

Sequence of PCR primers used to amplify polymorphic restriction enzyme sites within the $R B I$ gene.

\begin{tabular}{llc}
\hline \multirow{2}{*}{$\begin{array}{l}\text { Polymorphic } \\
\text { site }\end{array}$} & \multicolumn{2}{c}{ Primers } \\
\cline { 2 - 3 } $\begin{array}{l}\text { BamHI } \\
\text { XbaI }\end{array}$ & Sense & Antisense \\
\hline
\end{tabular}



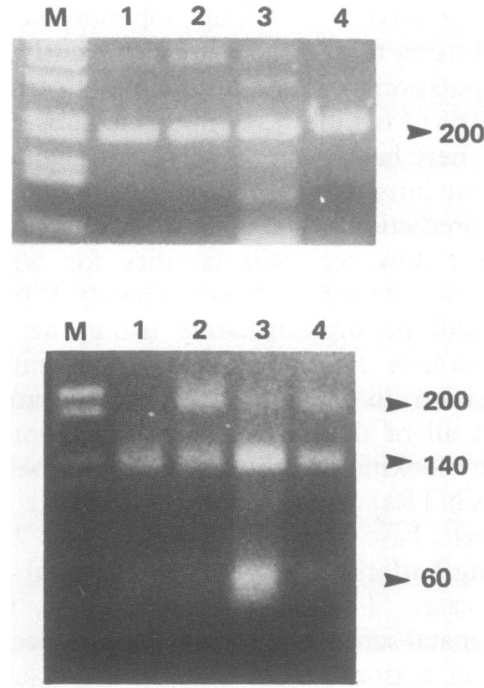

Figure 2 PCR amplification of the polymorphic BamHI site from DNA samples from the members of family $R B-29$ (above). In all cases a dominant band of the expected size, $\pm 200 \mathrm{bp}$ long, is seen as well as fainter, non-specific bands in some cases. The amplified DNA from each patient was digested with BamHI (below). The marker lane (M) in each case contains the Gibco $B R L I \mathrm{~kb}$ ladder. The father (lane 1 ) is homozygous for the lower allele but the mother (lane 2) is heterozygous. Although a weak residual upper band is seen in this example, in DNA extracted from the tissue section representing the affected dead child (lane 3), the dominant bands are those for the lower allele indicating that this patient is homozygous for the allele. The unaffected child (lane 4) is heterozygous indicating that the $R b$ gene is segregating with the lower allele from the mother.

no evidence of $\mathrm{Rb}$ at the time of referral but, although the peak age for hereditary tumours is 10 to 14 months, he is still at risk for developing a tumour. In any case he could still be an apparently unaffected gene carrier which is known to occur in approximately $10 \%$ of cases. ${ }^{1}$ To establish phase unequivocally it was essential, therefore, to analyse DNA from tissue from the dead child. No blood samples had been saved and no necropsy was performed ${ }^{27}$ but during the treatment of the rhabdomyosarcoma a tooth was removed. Attached to its base was a small piece of tumour which had been fixed in formalin and embedded in wax. We were able to obtain tissue sections from this tumour material for analysis.

The DNA sequences flanking the polymorphic restriction enzyme sites in RB1 identified by probes $M 1.8^{20}$ and PRO $.6^{19}$ have been established. Using these sequences, oligonucleotide primers have been designed (see Materials and methods) to analyse the polymorphic sites using PCR. Using DNA from the tissue section from the dead child's second tumour, PCR products around both polymorphic sites were generated. For the BamHI polymorphism an approximately 200 bp genomic DNA fragment containing the intron 1 splice donor site was amplified (fig 2, top). The polymorphic BamHI site is located within the amplified fragment $50 \mathrm{bp}$ from the $3^{\prime}$ end. Thus, fragments of $140 \mathrm{bp}$ and $60 \mathrm{bp}$ are generated after BamHI digestion. Using this polymorphism the results were unequivocal; the mother is heterozygous and the affected daughter homozygous for the lower allele (fig 2, bottom). Since the as yet unaffected son is also heterozygous we would predict that the mutant gene, therefore, is segregating with the lower $(140 / 60$ bp) allele. Using the other set of primers (table) an approximately 945 bp genomic DNA fragment containing the polymorphic $X b a I$ site was amplified. $\mathrm{XbaI}$ digestion of this fragment identifies two alleles; an upper allele $945 \mathrm{bp}$ long and a lower allele consisting of two fragments $630 \mathrm{bp}+315 \mathrm{bp}$ long. At the $\mathrm{XbaI}$ locus (fig 3) the mother, the father, and the surviving child are all heterozygous. The dead child was homozygous for the lower allele indicating that the $\mathbf{R b}$ mutation is segregating with this allele.

The DNA extracted from the tissue sections was degraded, in the size range of 50 to $1500 \mathrm{bp}$ (fig 4). Owing to the cross linking of the DNA with formalin during the fixation process, smaller sizes are overrepresented although this did not present a problem in analysing the $180 \mathrm{bp}$ sequence flanking the $\mathrm{BamHI}$ polymorphism, yields of PCR product being relatively good. For the larger 945 bp fragment, however, PCR product yields were somewhat smaller. We interpret this to mean that, because of the fragmented nature of the DNA removed from the formalin fixed tissue, there are fewer intact molecules of the appropriate size in the DNA used as template in the PCR reaction. The DNA thus generated was used directly for restriction enzyme digestion where, although left for six to 24 hours, digestion was sometimes incomplete,

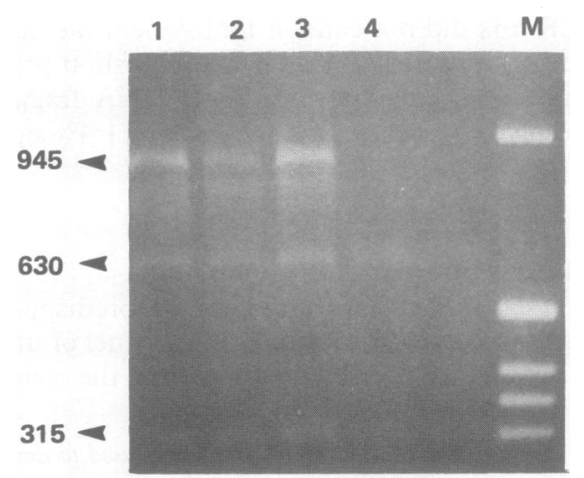

Figure 3 Segregation of the alleles for the polymorphic XbaI site in family $R B-29$. The father (lane 1) and mother (lane 2) are both heterozygous as is the unaffected child (lane 3 ). The dead affected child (lane 4) is homozygous for the lower allele. The $R b$ gene is therefore segregating with the lower allele from the mother. $M=$ marker lane containing $1 k b D N A$ ladder (Gibco-BRL). 


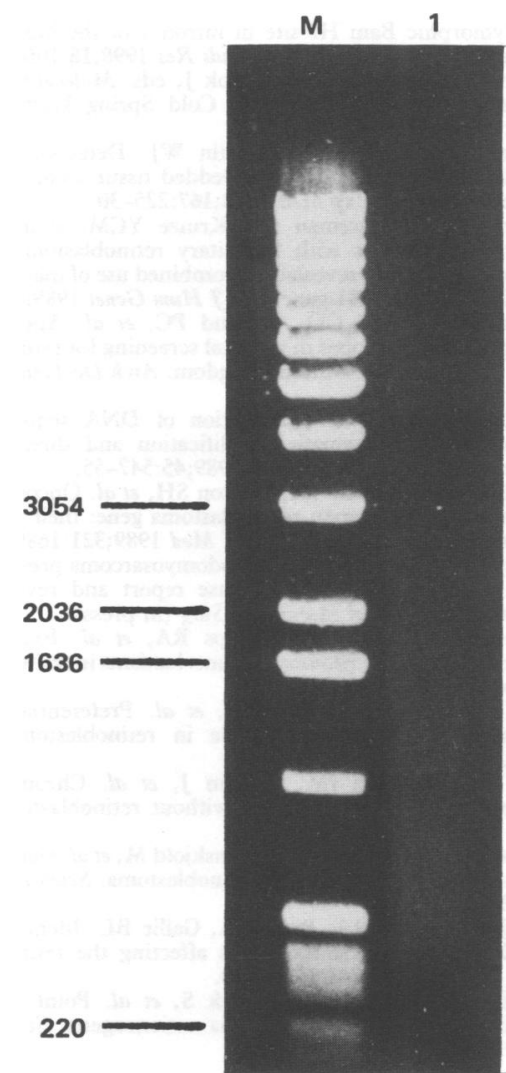

Figure 4 Size range of DNA extracted from the formalin fixed, paraffin embedded tissue. One tenth of the extracted DNA (lane 1) was run on a $0.6 \%$ agarose gel and stained with ethidium bromide. A smear is seen between $200 \mathrm{bp}$ and $3 \mathrm{~kb}$. The marker lane $(M)$ contains DNA from a 1 kb ladder (Gibco-BRL).

as shown in fig 2 . We have noted this same finding in several other cases where subjects are known to be homozygous for the lower allele from conventional Southern blotting/radiolabelled probing. The relative intensity of the band caused by DNA molecules resistant to digestion, however, was significantly weaker than in 'true' heterozygotes (fig 2). Repeated amplification and digestion of DNA isolated from different tissue sections showed that, in some cases, this upper band was absent. It is possible, therefore that this finding varies in relation to the purity of the extracted DNA.

It is possible that the tumour tissue used in this analysis is not truly representative of normal tissue from the patient. Loss of heterozygosity is frequently reported in retinoblastoma tissue, osteosarcomas, and soft tissue sarcomas. ${ }^{17} 28-30$ However, it is consistent with the theory of 'exposure' of recessive alleles in these childhood tumours that the mutant allele is retained. ${ }^{26}{ }^{31-33}$ This must also be expected to be the case in the rhabdomyosarcoma used in this study if loss of heterozygosity had occurred. Using the PRO.6 polymorphisms, however, since both parents are heterozygous their daughter could have been constitutionally heterozygous, inheriting the upper allele from the father. Whether their daughter is homozygous for the lower allele or it has been reduced to homozygosity in this case, in the tumour the result is still the same; the tumour predisposition gene cosegregates with the lower allele. From our linkage analysis using the BamHI polymorphism our prediction is that it is the lower allele which cosegregates with the mutant allele. Here loss of heterozygosity is not relevant to the argument since the father is homozygous and must contribute the lower allele to his children. Since the mother also contributes the lower allele, associated with the mutant gene, her daughter could not have been constitutionally heterozygous. Since both parents are heterozygous for the PRO.6 polymorphism, carrier status can only be confirmed or otherwise in $50 \%$ of future offspring but results will be unequivocal for the BamHI polymorphism. Taken together these tests will allow counselling of this family in the future.

The use of DNA from formalin fixed tissue in PCR has improved our capability to analyse mutations in $\mathrm{Rb}$ families. As long as DNA is available from key dead family members linkage phase can be established. The identification of the specific mutations in apparently sporadic cases will soon be possible via direct sequencing of the amplified DNA. Tumour tissue from many patients now approaching child bearing age exists as fixed material in pathology archives. Using this material and the methods described here, accurate genetic counselling is now available for many of these families.

We would like to thank C Brookes for helpful discussions about the dead child and the pathology department of the Royal Liverpool Children's Hospital, Alder Hey, for providing the tissue sections. We are grateful to Dr J Pritchard for critical reading of the manuscript. Zerrin Onadim is supported by a grant from the David Allen Retinoblastoma Appeal.

1 Vogel W. The genetics of retinoblastoma. Hum Genet 1979;52:

$1-54$.
2 Knudson AG. Mutation and cancer: statistical study of retinoblastoma. Proc Natl Acad Sci USA 1971;68:820-3.
bend

3 Abramson DH, Ellsworth RM, Kitchin FD, Tung G. Second nonocular tumours in retinoblastoma survivors. Are they radiation-induced? Ophthalmology 1984;91:1351-5.

4 Draper GJ, Sanders BM, Kingston JE. Second primary neoplasms in patients with retinoblastoma. $\mathrm{Br} \mathcal{F}$ Cancer 1986;53: $661-71$.

5 Lele KP, Penrose LS, Stallard HB. Chromosome deletion in a case of retinoblastoma. Ann Hum Genet 1963;27:171-4.

6 Yunis JJ, Ramsay N. Retinoblastoma and subband deletion of chromosome 13. Am f Dis Child 1978;132:161-3.

7 Sparkes RS, Sparkes MC, Wilson MG, et al. Regional assignment 
of genes for human esterase $D$ and retinoblastoma to chromosome band 13q14. Science 1980;208:1042-4.

8 Sparkes RS, Murphree AL, Lingua RW, et al. Gene for hereditary retinoblastoma assigned to human chromosome 13 by linkage to esterase-D. Science 1983;217:971-3.

9 Cowell JK, Hungerford J, Rutland P, Jay M. A chromosomal breakpoint which separates the esterase $D$ and retinoblastoma predisposition loci in a patient with $\operatorname{del}(13)(q 14-q 31)$. Cancer Genet Cytogenet 1987;27:27-31.

10 Lalande M, Dryja TP, Schreck RR, Shipley J, Flint A, Latt SA. Isolation of human chromosome 13-specific DNA sequences cloned from flow sorted chromosomes and potentially linked to the retinoblastoma locus. Cancer Genet Cytogenet 1984;13: 283-95.

11 Dryja TP, Rapaport JM, Joyce JM, Petersen RA. Molecular detection of deletions involving band q14 of chromosome 13 in retinoblastomas. Proc Natl Acad Sci USA 1986;83:7391-4.

12 Friend SH, Bernards R, Rogelj S, et al. A human DNA segment with properties of the gene that predisposes to retinoblastoma and osteosarcoma. Nature 1986;323:643-6.

13 Lee WH, Bookstein R, Hong F, Young L, Shew JY, Lee EP. Human retinoblastoma susceptibility gene: cloning, identification and sequence. Science 1987;235:1394-9.

14 Fung YT, Murphree AL, T'Ang A, Qian J, Hinrichs SH, Benedict WF. Structural evidence for the authenticity of the human retinoblastoma gene. Science 1987;236:1657-61.

15 Wiggs J, Nordenskjeld M, Yandell D, et al. Prediction of the risk of hereditary retinoblastoma using DNA polymorphisms within the retinoblastoma gene. $N$ Engl f Med 1988;318:151-7.

16 Mitchell CD, Nicolaides K, Kingston J, Hungerford J, Jay M, Cowell JK. Prenatal exclusion of hereditary retinoblastoma. Lancet 1988;i:826.

17 Friend SH, Horowitz JM, Gerber MR, et al. Deletions of a DNA sequence in retinoblastomas and mesenchymal tumours: organization of the sequence and its encoded protein. Proc Natl Acad Sci USA 1987;84:9059-63.

18 McGee TL, Yandell DW, Dryja TP. Structure and partial genomic sequence of the human retinoblastoma susceptibility gene. Gene 1989;80:119-28.

19 McGee TL, Cowley GS, Yandell DW, Dryja TP. Detection of the Xbal RFLP within the retinoblastoma locus by PCR. Nucleic Acids Res 1990;18:207.

20 Bookstein R, Lai CC, Lee HT, Lee WH. PCR-based detection of a polymorphic Bam HI site in intron 1 of the human retinoblastoma (RB) gene. Nucleic Acids Res 1990;18:1666.

21 Maniatis T, Fritsch EF, Sambrook J, eds. Molecular cloning: $a$ laboratory manual. New York: Cold Spring Harbour Press, 1982:406.

22 Shibata DK, Arnheim N, Martin WJ. Detection of human papilloma virus in paraffin-embedded tissue using polymerase chain reaction. F $\operatorname{Exp} M e d$ 1988;167:225-30.

23 Scheffer H, Te Meerman GJ, Kruize YCM, et al. Linkage analysis of families with hereditary retinoblastoma:nonpenetrance of mutation, revealed by combined use of markers within and flanking the RB1 gene. Am $\mathcal{Y}$ Hum Genet 1989;45:252-60.

24 Onadim Z, Mitchell CD, Rutland PC, et al. Application of intragenic DNA probes in prenatal screening for retinoblastoma gene carriers in the United Kingdom. Arch Dis Child 1990;65: 651-6.

25 Yandell DW, Dryja TP. Detection of DNA sequence polymorphisms by enzymatic amplification and direct genomic sequencing. Am $\mathcal{f}$ Hum Genet 1989;45:547-55.

26 Yandell DW, Campbell TA, Dayton SH, et al. Oncogenic point mutations in the human retinoblastoma gene: their application to genetic counselling. N Engl f Med 1989;321:1689-95.

27 Brookes CN, Van Velzen D. Rhabdomyosarcoma presenting as a facial swelling in a child: a case report and review of the literature. Br f Oral Maxillofac Surg (in press).

28 Cavenee WK, Dryja TP, Phillips RA, et al. Expression of recessive alleles by chromosomal mechanisms in retinoblastoma. Nature 1983;305:779-84.

29 Zhu X, Dunn JM, Phillips RA, et al. Preferential germline mutation of the paternal allele in retinoblastoma. Nature 1989;340:312-3.

30 Dryja TP, Rapaport JM, Epstein J, et al. Chromosome 13 homozygosity in osteosarcoma without retinoblastoma. $\mathrm{Am} \mathcal{F}$ Hum Genet 1986;38:59-66.

31 Cavenee WK, Hansen MF, Nordenskjold M, et al. Genetic origin of mutations predisposing to retinoblastoma. Science 1985;228 501-3.

32 Dunn JM, Phillips RA, Becker A, Gallie BL. Identification of germline and somatic mutations affecting the retinoblastoma gene. Science 1988;241:1797-800.

33 Horowitz JM, Yandall DW, Park S, et al. Point mutational inactivation of the retinoblastoma antioncogene. Science 1989; 243:937-40. 